\title{
Effects of Dietary Protein Level on Growth and Ammonia Excretion of Leopard Coral Grouper, Plectropomus leopardus (Lacepede, 1802)
}

(Kesan Pemakanan Tahap Protein terhadap Pertumbuhan dan Perkumuhan Amonia pada Kerapu Bara Plectropomus leopardus (Lacepede, 1802))

\section{S. XIA, Z. SUN*, S. FENG Z.ZHANG, M.M. RAHMAN \& M. RAJKUMAR}

\begin{abstract}
The effects of dietary protein level on the growth performance and ammonia excretion of the leopard coral grouper, Plectropomus leopardus were investigated for eight weeks. Fish were fed diets with 40, 45, 50, 55 and $60 \%$ crude protein levels in separate recirculating systems. Fish fed with the 50\% crude protein containing diet showed the best ingestion rate, which was significantly higher than that found in the other groups. As the dietary protein level increased, the specific growth rate increased significantly and it reached the highest level at $50 \%$ crude protein containing diet. Based on the results of all measured parameters $50 \%$ protein containing diet was the best among all test diets. The regression equation for dietary protein level versus ammonia excretion indicated that the optimal dietary protein level with the least ammonia excretion was 53.14\%. More research is still needed to elucidate the effects of 53.14\% crude protein containing diet on the specific growth rate, feed conversion ratio, protein efficiency ratio and ingestion rate of leopard coral grouper before recommending this level. Until then, $50 \%$ protein containing diet can be recommended for leopard coral grouper culture in the recirculation system.
\end{abstract}

Keywords: Ammonia excretion; dietary protein level; Plectropomus leopardus; water quality

ABSTRAK

Kesan tahap protein pemakanan terhadap pertumbuhan dan perkumuhan amonia pada kerapu bara, Plectropomus leopardus telah dikaji selama lapan minggu. Ikan telah diberi makan dengan diet tahap protein mentah 40, 45, 50, 55 dan $60 \%$ dalam sistem peredaran air berasingan. Ikan yang diberi makan diet dengan kandungan $50 \%$ protein mentah menunjukkan kadar pengambilan terbaik, jauh lebih tinggi daripada yang terdapat di dalam kumpulan-kumpulan lain. Apabila tahap protein dalam diet meningkat, kadar pertumbuhan khusus meningkat dengan ketara dan mencapai tahap tertinggi pada diet yang mengandungi 50\% protein mentah. Berdasarkan keputusan semua parameter yang diambil, diet mengandungi 50\% protein adalah yang terbaik di antara semua ujian diet. Persamaan regresi untuk tahap protein dalam diet berbanding perkumuhan amonia menunjukkan tahap protein pemakanan yang optimum dengan kurang perkumuhan amonia adalah 53.14\%. Lebih banyak kajian perlu dijalankan untuk menjelaskan kesan diet yang mengandungi 53.14\% protein mentah terhadap kadar pertumbuhan spesifik, nisbah pertukaran makanan, nisbah kecekapan protein dan kadar pemakanan kerapu bara sebelum ia dapat disyorkan. Sehingga ini, diet yang mengandungi $50 \%$ protein dapat disyorkan kepada penternakan kerapu bara dalam sistem peredaran air semula.

Kata kunci: Amonia perkumuhan; kualiti air; Plectropomus leopardus; tahap protein pemakanan

\section{INTRODUCTION}

Among coral groupers, the leopard coral grouper, Plectropomus leopardus (Lacepede 1802) is one of the favorite target fish for all sectors of the fishery because it enjoys high consumer preference and market value locally and overseas (Ayling et al. 2000). Its natural habitat includes open seas and coral reefs. However, it is commonly found in coral-rich areas of lagoon reefs and mid-shelf reefs (Kailola et al. 1993; Kuiter \& Tonozuka 2001). The leopard coral grouper population is declining on the Great Barrier Reef and this problem is further aggravated by the increasing harvest in Australia (Ayling et al. 2000). Many other countries have also experienced declining landings, implying that the population of leopard coral grouper may be decreasing
(Russell 2007). Depletion of natural stocks together with high commercial value has encouraged stock enhancement and aquaculture for leopard coral grouper. Successful hatching in 2009 enhanced aquaculture of this species in China where land-based intensive culture is one of the main culture methods of this species. To date, studies of leopard coral grouper have mainly focused on its ecology, embryonic development, early life history, molecular classification and behavior (Kenzo et al. 2008; Yang et al. 2012; Zhu \& Yue 2008). Only a few studies focused on nutrition of this species. However, study on the optimization of protein in the formulated diet of this species is still lacking.

Protein is one of the most expensive and important ingredients in fish feeds. Dietary protein can affect growth 
and health of cultured fish as well as maintenance of a good farming environment (Rahman et al. 2008a, 2008c, 2012; Rahman \& Verdegem 2010). Therefore, it should be carefully apportioned to meet the needs of the cultured organisms (Rajkumar et al. 2013; Yang et al. 2002). If excessive protein is supplied in the diet, only part of it will be used to synthesize new tissues and the surplus will be metabolized as an energy source (Guo et al. 2012). The main end product of protein metabolism in aquatic animals is ammonia, thus fish diet also affects water quality via ammonia excretion (Rahman \& Meyer 2009; Rahman et al. 2008b, 2008d, 2010). The appropriate amount of protein in the formulated diet can enhance growth and reduce ammonia excretion. Therefore, optimizing protein in the fish diet is very important for the successful aquaculture of any fish species (Rahman \& Verdegem 2007).

Considering the above issues, the goals of this study were to elucidate the effects of different levels of dietary protein on the ammonia excretion and growth of leopard coral grouper and water quality in the culture system.

\section{MATERIALS AND METHODS}

\section{FEED FORMULATION}

Five experimental diets containing 39.9, 44.1, 50.7, 56 and $61.4 \%$ crude protein $(\mathrm{CP})(\mathrm{CP} 40, \mathrm{CP} 45, \mathrm{CP} 50, \mathrm{CP} 55$ and CP60, respectively) were formulated using feed formulation software REFS3000 (Beijing Resource Group, Beijing City, P.R. China). Soybean meal and defatted fish meal were used as the protein sources in the diets and wheat flour was the carbohydrate source. All ingredients (Table 1) were ground in an ultrafine pulverizer, sieved to a particle size $<75 \mu \mathrm{m}$ and mixed. Pellets were generated using a meat mincer machine (TK-12, Shanghai Yingxiao
Food Apparatus Co., Ltd., Shanghai, P.R. China). Each of the different protein level diets was mixed with fresh water $(2: 1)$, passed through the mincer machine and dried at $60^{\circ} \mathrm{C}$ until a constant weight was reached. The pellets were then ground and sieved to a particle size between 3 and $4 \mathrm{~mm}$ prior to use.

\section{EXPERIMENTAL ANIMALS AND FEEDING TRIAL}

Healthy leopard coral groupers were collected from the Tianjin Shengyi Aquatic company located in Tianjin City, P.R. China. One hundred eighty fish with initial body weight of $36.4 \pm 1.5 \mathrm{~g}$ were randomly stocked into 15 glass aquaria (size of aquaria was $80 \times 40 \times 40 \mathrm{~cm}^{3}$ ) in equal numbers $(n=12)$ into five recirculating systems to form five triplicate groups. Prior to the experiment, the fish were acclimatized to the laboratory conditions in a recirculating system for one week. During the experiment, aeration was provided continuously and mean water quality parameters were maintained as temperature $26 \pm 2^{\circ} \mathrm{C}$, salinity $30 \pm 2 \mathrm{gL}^{-1}$ and dissolved oxygen $>5 \mathrm{mgL}^{-1}$.

The five groups of fish were fed with the five different types of diet twice a day at 9:00 $\mathrm{h}$ and 15:00 h. Uneaten feed and feces were siphoned from the tanks $24 \mathrm{~h}$ later and separated carefully from each other. The uneaten feed was dried at $60^{\circ} \mathrm{C}$ to a constant weight to calculate feed consumption by fish. At the end of the experiment, all fish in each tank were harvested $24 \mathrm{~h}$ after the last feeding and weighed. Specific growth rate (SGR), ingestion rate (IR), feed conversion ratio (FCR) and protein efficiency ratio (PER) were calculated using the following equations:

$$
\begin{aligned}
& \text { SGR }\left(\% \mathrm{~d}^{-1}\right)=100 \times\left[\ln \mathrm{W}_{2}-\ln \mathrm{W}_{1}\right] / \mathrm{T} ; \\
& \text { FCR }=\mathrm{C} /\left(\mathrm{W}_{2}-\mathrm{W}_{1}\right) ; \\
& \mathrm{IR}\left(\mathrm{mg} \mathrm{ind}^{-1} \mathrm{~d}^{-1}\right)=\mathrm{C} /(\mathrm{N} * \mathrm{~T}) \text { and } \\
& \text { PER }=\left(\mathrm{W}_{2}-\mathrm{W}_{1}\right) /(\mathrm{C} * \mathrm{M})
\end{aligned}
$$

TABLE 1. Ingredients and chemical composition of trial diets (air-dry basis $\mathrm{g} \mathrm{kg}^{-1}$ )

\begin{tabular}{lccccc}
\hline Ingredients & CP40 & CP45 & CP50 & CP55 & CP60 \\
\hline Peru fish meal & 339.4 & 402.0 & 464.6 & 527.2 & 589.8 \\
Wheat gluten & 111.6 & 132.3 & 153.0 & 173.7 & 194.5 \\
Soybean protein concentrate & 37.2 & 44.1 & 51.0 & 57.9 & 64.8 \\
Wheat powder & 461.6 & 371.4 & 281.1 & 190.9 & 100.6 \\
Fish oil & 20.1 & 20.1 & 20.1 & 20.1 & 20.1 \\
Soybean lecithin & 20.1 & 20.1 & 20.1 & 20.1 & 20.1 \\
Vitamin premix $^{1}$ & 5.0 & 5.0 & 5.0 & 5.0 & 5.0 \\
Mineral premix $^{2}$ & 5.0 & 5.0 & 5.0 & 5.0 & 5.0 \\
Total & 1000 & 1000 & 1000 & 1000 & 1000 \\
Chemical composition $\left(\mathrm{g} \mathrm{kg}^{-1}\right)$ & & & & 920.6 & 928.6 \\
Dry matter & 916.6 & 924.6 & 919.6 & 559.8 & 614.1 \\
Crude protein & 398.8 & 441.3 & 507.2 & 105.7 & 111.2 \\
Crude lipid & 75.6 & 82.9 & 91.8 & 133.5 & 145.1 \\
Crude ash & 95.1 & 107.3 & 122.0 & & \\
\hline
\end{tabular}

${ }^{1}$ Vitamin premix ( $\mathrm{g} \mathrm{kg}^{-1}$ premix) provided the following levels of nutrients: thiamin $\mathrm{HCl}, 0.35$; riboflavin, 4.5; pyridoxine $\mathrm{HCl}, 1.0$; DL-Ca-pantothenate, 5.0; vitamin A acetate $\left(20000 \mathrm{IUg}^{-1}\right), 4.0$; nicotinic acid, 5.0; biotin, 0.05; vitamin B12, 0.002; folic acid, 0.38; Vitamin C, 200 ; vitamin D3 (400 $000 \mathrm{IUg}^{-1}$ ), 0.004 ; menadione, 2.0; inositol, 10.0; DL-a-tocopheryl acetate $\left(250 \mathrm{IUg}^{-1}\right), 8.0$; a-cellulose, 759.71

${ }^{2}$ Mineral premix $\left(\mathrm{g} 100 \mathrm{~g}^{-1}\right.$ ) provided the following levels of nutrients: cobalt chloride, 0.004 ; zinc sulphate heptahydrate, 10.2; cupric sulphate pentahydrate, $0.30 ;$ potassium iodide, 0.06 ; ferrous sulphate, 10.5; sodium selenite, 0.022 ; manganous sulphate monohydrate, 0.650 ; magnesium sulphate heptahydrate, 16.5 ; filler, 61.76 
where $\mathrm{W}_{1}$ and $\mathrm{W}_{2}$ are initial and final average individual body weights of fish in each tank, respectively; $\mathrm{T}$ is the duration of the experiment; $\mathrm{C}$ is the feed consumed (dry weight basis); $\mathrm{N}$ is the number of fish in each aquarium; and $\mathrm{M}$ is the dietary protein content.

\section{AMMONIA EXCRETION}

Ammonia excretion was analyzed for $12 \mathrm{~h}$ on the last day of week 5 . The different diets were placed in each tank at 9:00 h in the morning. Uneaten feed was siphoned from the tanks at 9:30 h to calculate feed consumption by fish. The total ammonia (ammonia/ammonium in water) concentration was determined at 9:30 h and 12:00 h using the phenol-hypochlorite method (Solorzano 1969). Ammonia excretion was calculated according to Russell (2007) using the equation: Ammonia excretion $[\mathrm{mg}(\mathrm{g}$ diet $\left.)^{-1}\right]=\left[\right.$ final ammonia content $\left(\mathrm{mgL}^{-1}\right)$ - initial ammonia content $\left.\left(\mathrm{mgL}^{-1}\right)\right] \times$ water volume $(\mathrm{L}) /$ feed intake $(\mathrm{g})$.

\section{WATER QUALITY}

The water quality parameters were measured on the last day of week 4 in the morning before supplying feed. To measure water quality, a $250 \mathrm{~mL}$ water sample was removed from each tank. The sample was filtered through a cellulose membrane filter before analysis. Ammonia concentration was measured using phenol-hypochlorite method (Solorzano 1969), nitrite concentration was measured using the hydrochloric acid naphthalene ethylenediamine method (Grasshoff 1999) and phosphate concentration was measured using the phosphorus molybdenum blue spectrophotometry method (Taguchi et al. 1985).

\section{STATISTICAL ANALYSIS}

All data were checked for normality and homogeneity of variance before analysis. Growth performance, ammonia excretion and water quality data were subjected to one-way analysis of variance (ANOVA). If any effect was significant, difference between the means were analyzed by Duncan's test for unplanned multiple comparison of mean $(p<0.05)$. All statistical analyses were performed using SPSS software (version 15.0; SPSS, Chicago, IL, USA).

\section{RESULTS}

\section{GROWTH PERFORMANCE}

The growth performance parameters differed significantly $(p<0.05)$ among groupers fed at the different protein level diets. The SGR of grouper in the CP60, CP55 and CP50 groups were significantly $(p<0.05)$ higher than those in the CP45 and CP40 groups (Figure 1). There was no significant difference between CP60, CP55 and CP50 groups on grouper's SGR, which was statistically the same in the CP45 and CP40 groups. FCR of grouper decreased significantly with increasing dietary protein content (Figure 2). The FCR

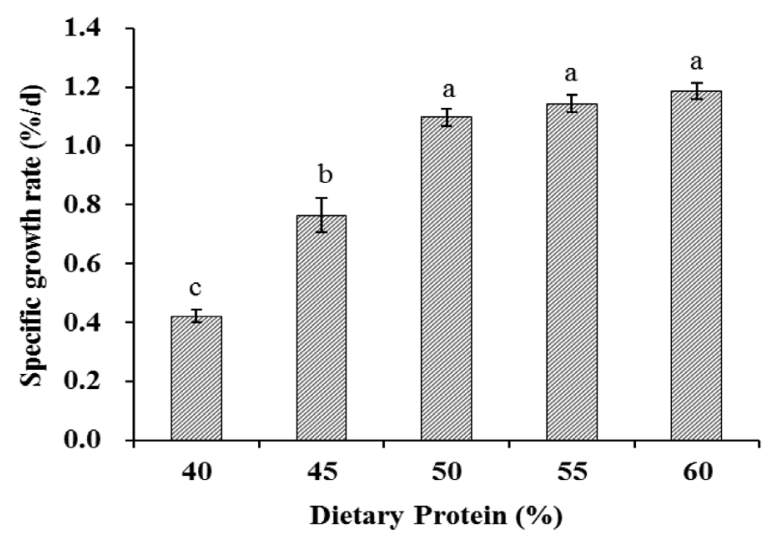

FIGURE 1. Effect of dietary protein levels on specific growth rate of leopard coral grouper based on one-way ANOVA. Bar with no superscript in common differ significantly $(p<0.05)$.

Data are mean \pm standard error

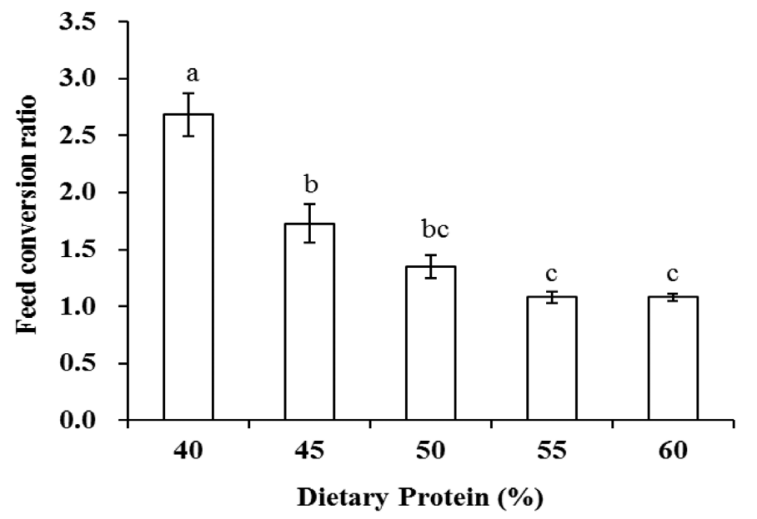

FIGURE 2. Effect of dietary protein levels on feed conversion ratio of leopard coral grouper based on one-way ANOVA. Bar with no superscript in common differ significantly $(p<0.05)$.

Data are mean \pm standard error

of grouper in the CP55 and CP60 groups were significantly $(p<0.05)$ lower than those in the CP45 and CP40 groups $(p<0.05)$. There was no significant difference $(p>0.05)$ between CP60, CP55 and CP50 groups on grouper's FCR, which was statistically $(p>0.05)$ similar in the CP45 and CP50 groups. The PER increased first and then decreased as the dietary protein level increased and the highest value occurred at CP55 (Figure 3). No significant differences ( $p>0.05$ ) were found for PER among the CP60, CP55 and CP50 groups. The highest IR was observed in the CP50 group, followed by the CP60, СP50, CP45 and CP40 groups (Figure 4).

\section{AMMONIA-NITROGEN PRODUCTION}

Figure 5 shows the ammonia excretion of leopard coral grouper fed at the different test diets. Dietary protein levels significantly $(p<0.05)$ affected ammonia excretion. As the dietary protein level increased, the ammonia concentration first declined and then increased significantly. The highest 


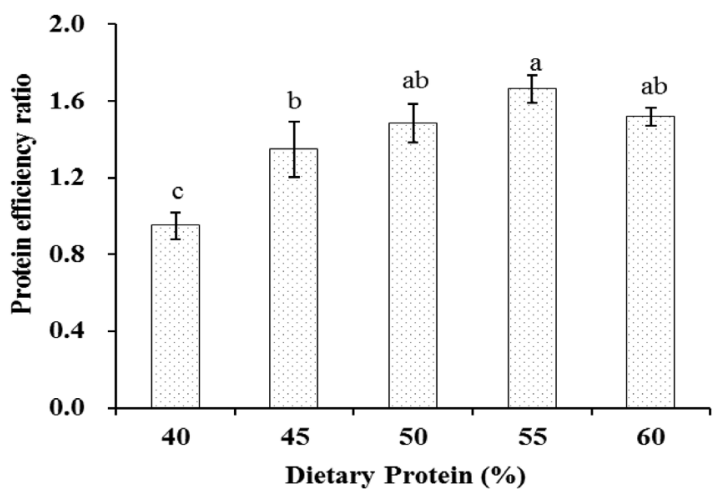

FIGURE 3. Effect of dietary protein levels on protein efficiency ratio of leopard coral grouper based on one-way ANOVA. Bar with no superscript in common differ significantly $(p<0.05)$.

Data are mean \pm standard error

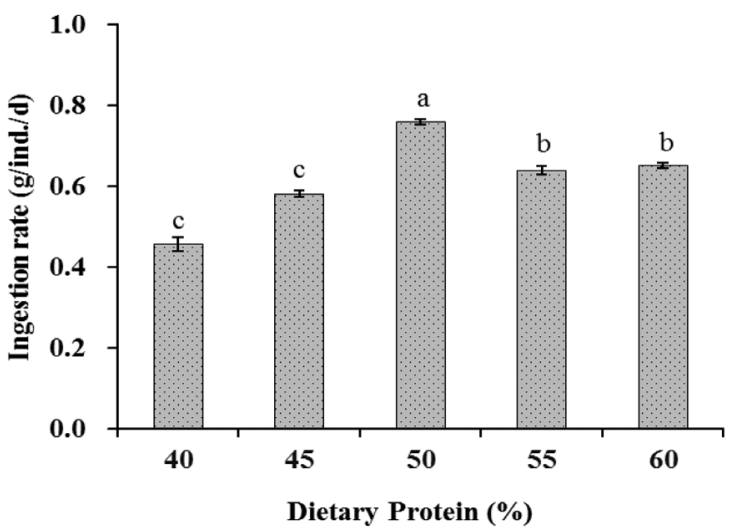

FIGURE 4. Effect of dietary protein levels on ingestion rate of leopard coral grouper based on one-way ANOVA. Bar with no superscript in common differ significantly $(p<0.05)$. Data are mean \pm standard error

ammonia excretion by leopard coral grouper was observed in the $\mathrm{CP} 40$ group, while the lowest was observed in that CP55 group. There was no significant difference $(p>0.05)$ between CP45 and CP60 groups on the ammonia excretion by leopard coral grouper. The regression equation for the dietary protein level versus ammonia excretion was $\mathrm{y}=$ $0.0067 x^{2}-0.7154 x+20.4\left(r^{2}=0.9244, p<0.05\right)$ (Figure 6). Using this equation, the optimal dietary protein level with the least ammonia excretion was calculated to be $53.14 \%$.

\section{WATER QUALITY}

The ammonia, nitrite and phosphate concentrations of water varied significantly $(p<0.05)$ with dietary protein level (Table 2). The highest ammonia concentration was observed in the aquaria water supplied with $61.4 \%$ crude protein diet (CP60), while lowest was observed in the aquaria water supplied with $56 \%$ crude protein diet. Ammonia concentrations were statistically similar in the aquaria water supplied with $39.9,44.1$ and $50.7 \%$ crude protein containing diets. The nitrite concentrations

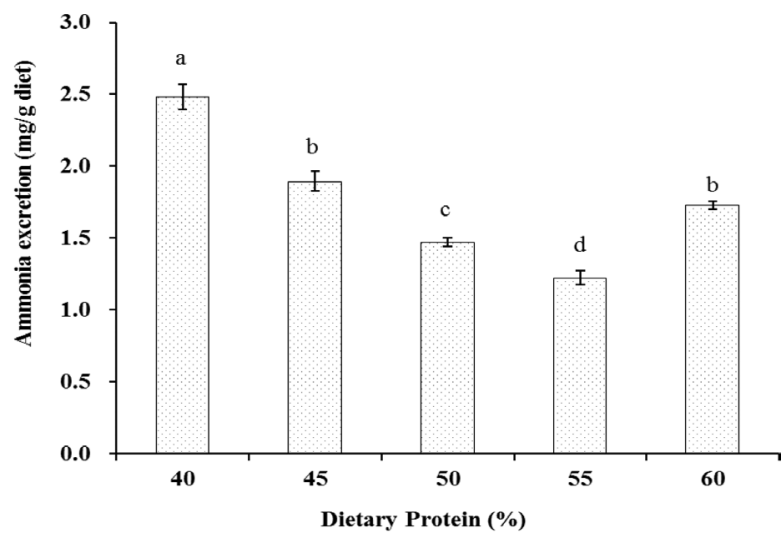

FIGURE 5. Effect of dietary protein levels on ammonia excretion of leopard coral grouper based on one-way ANOVA. Bar with no superscript in common differ significantly $(p<0.05)$. Data are mean \pm standard error

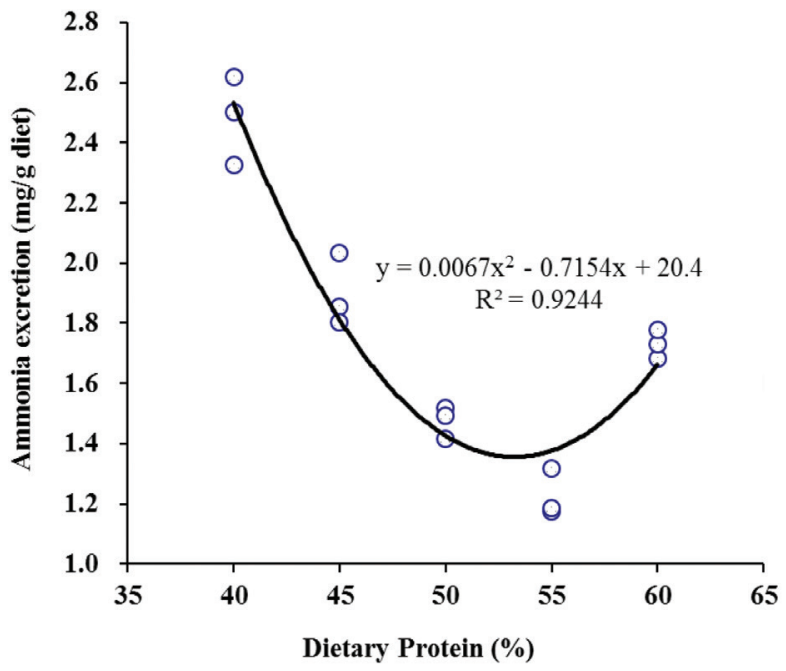

FIGURE 6. Regression analysis illustrating the relationship between dietary protein levels and the ammonia excretion in leopard coral grouper

were higher in the aquaria water supplied with $61.4 \%$ crude protein diet than those tanks that were supplied with 39.9, 44.1, 50.7 and 56\% crude protein diets. The nitrite concentration was similar in the tanks with 39.9, $44.1,50.7$ and $56 \%$ crude protein diets. Phosphate concentration ranged between 0.273 and $0.420 \mathrm{mg} / \mathrm{L}$ and was positively correlated with the dietary protein levels when the dietary protein content was above $44.1 \%$. The phosphate concentration $(0.420 \pm 0.003)$ was the highest in the aquaria water supplied with $61.4 \%$ crude protein diet (CP60), followed by 55\%, 50.7\%, 39.9\% and $44.1 \%$ crude protein diet.

\section{DISCUSSION}

Increasing the protein content in the fish feed usually results in increased fish growth rate (Bibiano-Melo et al. 
TABLE 2. Effect of dietary protein level diets on water quality of leopard coral grouper based on one-way ANOVA. Data are mean \pm standard error

\begin{tabular}{lccccc}
\hline Parameter $(\mathrm{mg} / \mathrm{L})$ & CP40 & CP45 & CP50 & CP55 & CP60 \\
\hline Ammonia & $0.166 \pm 0.004^{\mathrm{b}}$ & $0.158 \pm 0.004^{\mathrm{b}}$ & $0.162 \pm 0.004^{\mathrm{b}}$ & $0.123 \pm 0.003^{\mathrm{c}}$ & $0.188 \pm 0.003^{\mathrm{a}}$ \\
Nitrite & $0.064 \pm 0.010^{\mathrm{b}}$ & $0.066 \pm 0.005^{\mathrm{b}}$ & $0.111 \pm 0.003^{\mathrm{b}}$ & $0.100 \pm 0.002^{\mathrm{b}}$ & $0.222 \pm 0.031^{\mathrm{a}}$ \\
Phosphate & $0.286 \pm 0.001^{\mathrm{c}}$ & $0.273 \pm 0.002^{\mathrm{d}}$ & $0.291 \pm 0.001^{\mathrm{c}}$ & $0.362 \pm 0.001^{\mathrm{b}}$ & $0.420 \pm 0.003^{\mathrm{a}}$ \\
\hline
\end{tabular}

Values in the same row with different superscripts differ significantly $(p<0.05)$

2006). This statement is true in the present study up to a certain point for leopard coral grouper. The SGR of leopard coral grouper increased with increasing dietary protein level up to $50.7 \%$ crude protein. This result concurs with Gunasekera et al. (2000) and Mohanty and Samantaray (1996). Gunasekera et al. (2000) used five different diets containing 40, 45, 50, 55 and $60 \%$ crude protein to culture murray cod, Maccullochella peelii peelii and observed the highest SGR in fish fed with $50 \%$ crude protein containing diet. Mohanty and Samantaray (1996) used almost similar diets to culture snakehead, Channa striata and observed the highest SGR in fish fed with $55 \%$ crude protein containing diet.

Based on the present observation, $50.7 \%$ crude protein containing diet may be considered as the optimal dietary protein level for leopard coral grouper culture. This statement is further supported by the feed conversion ratio, dietary protein ingestion rate and ammonia excretion by leopard coral grouper, which ingested the highest quantity of protein but excreted the lowest quantity of ammonia when fed with the $50.7 \%$ crude protein containing diet. However, regression analysis of dietary protein level versus ammonia excretion showed that the optimal dietary protein level was $53.14 \%$ for leopard coral grouper culture. This dietary protein level is within the range that allows for high growth rate and production of fish. According to NRC (1993), the dietary protein requirements for most fishes vary from 30 to $55 \%$ depending on species, size, source of protein and environmental conditions. Millikin (1982) reported that juvenile striped bass, Morone saxatilis required a diet containing $55 \%$ protein for their best growth. For commercial farming of juvenile Asian sea bass or other marine fish in China, feeds normally contain $45 \%$ or higher crude protein. The metabolism of carnivorous fish is generally adapted to high levels of dietary protein (Bibiano-Melo et al. 2006). Leopard coral grouper is piscivorous; juveniles mostly eat crustaceans especially prawns and adults feed on a variety of reef fish particularly damselfish. This piscivorous feeding habit may explain the requirement of relatively high levels of dietary protein for their high growth.

In this study, the protein efficiency ratio increased significantly when the dietary protein level was below $50 \%$. However, an opposite trend was almost obtained in case of ammonia excretion by leopard coral grouper. We observed a significant negative correlation $(r=-0.8541, p<0.01)$ between protein efficiency ratio and ammonia excretion by leopard coral grouper. This finding is in agreement with Kim et al. (1991) and Rychly (1980), who stated that the increased nitrogenous excretion is a consequence of using amino acids as energetic compounds and this process reduce protein efficiency ratio. When lipids are not available to provide the energy required for growth and activity, proteins are generally metabolized as energy instead and this situation leads to a lower protein efficiency ratio and higher ammonia excretion (Cho \& Kaushik 1985; Engin \& Carter 2001; Shiau \& Huang 1989).

Dietary proteins that are above the optimal levels influence ammonia excretion in fish and shrimp. For example, ammonia excretion is greatly increased by white-leg shrimp when the dietary protein level is more than $43 \%$ (Xia et al. 2010). Similarly, Jiang et al. (2005) observed that turbot, Scophthalmus maximus excreted much higher quantity of ammonia in the environment when the dietary protein content was $54.3 \%$ compared to $52.1 \%$. In the present study, leopard coral grouper excreted more ammonia when fed with $61.4 \%$ protein containing diet than the $56 \%$ protein containing diet. The reason might be the amino acids surplus from the $61.4 \%$ protein containing diet (Ballantyne 2001; Stone et al. 2003). According to Ballantyne (2001) and Stone et al. (2003), the amino acid surplus from protein-rich diets cannot be directly stored in fishes and they are deaminated and converted into energetic compounds. The augmented protein breakdown in fish results in an increased concentration of plasma ammonia, which is promptly excreted through the gills into the environment (van Waarde 1983; Yang et al. 2002).

In the present study, $53.14 \%$ protein containing diet produced the least ammonia in the culture system. However, nothing is known about the effects of $53.14 \%$ protein containing diet on SGR, FCR, PER and IR of the leopard coral grouper. Therefore, more research is still needed to elucidate the effects of $53.14 \%$ protein containing diet on SGR, FCR, PER and IR of the leopard coral grouper before recommending this level. Until then, 50.7\% protein containing diet can be recommended for leopard coral grouper culture in a recirculation system.

\section{ACKNOWLEDGEMENTS}

We would like to thank Yanguang Yu, Hongzhen You, Xueliang Yao for their help in the experiment. In particular, we would also like to thank two anonymous reviewers for professional revision of the manuscript. This research was supported by Tianjin Agricultural Science and Technology Achievement Transformation and Promotion project 
(No. 201103040), Natural Science Fund of Tianjin (No. 11JCYBJC08800), Tianjin Science and Technology Key Program (No. 12ZCZDNC01100).

\section{REFERENCES}

Ayling, R.D., Baker, S.E., Peek, M.L., Simon, A.J. \& Nicholas, R.J. 2000. Comparison of in vitro activity of danofloxacin, florfenicol, oxytetracycline, spectinomycin and tilmicosin against recent field isolates of Mycoplasma bovis. Veterinary Record 146: 745-747.

Ballantyne, J.S. 2001. Amino acid metabolism. Fish Physiology and Biochemistry 20: 77-107.

Bibiano-Melo, J.F., Lundstedt, L.M., Metón, I., Baanante, I.V. \& Moraes, G. 2006. Effects of dietary levels of protein on nitogenous metabolism of Rhamdia quelen (Teleostei: Pimelodidae). Comparative Biochemistry and Physiology Part A 145: 181-187.

Cho, C.Y. \& Kaushik, S.J. 1985. Effects of protein intake on metabolizable and net energy values of fish diets. In Nutrition and Feeding in Fish, edited by Cowey, C.B., Mackie, A.M. $\&$ Bell, J.G. London: Academic Press.

Engin, K. \& Carter, C.G. 2001. Ammonia and urea excretion rates of juvenile Australian short-finned eel (Anguilla australis australis) as influenced by dietary protein level. Aquaculture 194: 123-136.

Grasshoff, K. 1999. Methods of Seawater Analysis. 3rd ed. New York: Verlag Chime, Weinheim.

Gunasekera, R.M., de Silva, S.S., Collins, R.A., Gooley, G. \& Ingram, B.A. 2000. Effect of dietary protein level on growth and food utilization in juvenile Murray cod Maccullochella peelii peelii (Mitchell). Aquaculture Research 31: 181-187.

Guo, Z., Zhu, X., Liu, J., Han, D., Yang, Y., Lan, Z. \& Xie, S. 2012. Effects of dietary protein level on growth performance, nitrogen and energy budget of juvenile hybrid sturgeon, Acipenser baerii $\bigcirc \times$ A. gueldenstaedtii ${ }^{\top}$. Aquaculture 338-341: 89-95.

Jiang, K., Li, Y., Li, J., Wang, L. \& Wang, Y. 2005. Eco-nutrition requirement of protein for juvenile turbot (Scophthalmus maximus L.). Marine Science 29: 65-70.

Kailola, P.J., Williams, M.J., Stewart, P.C., Reichelt, R.E., McNee, A. \& Grieve, C. 1993. Australian Fisheries Resources. Canberra, Australia: Bureau of Resource Sciences.

Kenzo, Y., Kazuhisa, Y., Kimio, A., Masayuki, C., Koji, H. \& Shinichi, K. 2008. Influence of light intensity on feeding, growth, and early survival of leopard coral grouper (Plectropomus leopardus) larvae under mass-scale rearing conditions. Aquaculture 279: 55-62.

Kim, K., Kayes, T.B. \& Amundson, C.H. 1991. Purified diet development and re-evaluation of the dietary protein requirement of fingerling rainbow trout (Oncorhyncus mykiss). Aquaculture 96: 57-67.

Kuiter, R.H. \& Tonozuka, T. 2001. Pictorial guide to Indonesian reef fishes. Part 1. Eels-Snappers, Muraenidae-Lutjanidae. Zoonetics, Australia.

Millikin, M.R. 1982. Effects of dietary protein concentration on growth, feed efficiency, and body composition of age- 0 striped bass. Transactions of the American Fisheries Society 111: 373-378.

Mohanty, S.S. \& Samantaray, K. 1996. Effect of varying levels of dietary protein on the growth performance and feed conversion efficiency of snakehead Channa striata fry. Aquaculture Nutrition 2: 89-94.
National Research Council (NRC) 1993. Nutrient Requirements of Warm Water Fishes and Shellfishes. rev. ed. Washington, DC: National Academy Press.

Rahman, M.M. \& Verdegem, M.C.J. 2010. Effects of intra- and interspecific competition on diet, growth and behaviour of Labeo calbasu (Hamilton) and Cirrhinus cirrhosus (Bloch). Applied Animal Behaviour Science 128: 103-108.

Rahman, M.M. \& Meyer, C.G. 2009. Effects of food type on diet behaviours of common carp Cyprinus carpio L. in simulated aquaculture pond conditions. Journal of Fish Biology 74: $2269-2278$.

Rahman, M.M. \& Verdegem, M.C.J. 2007. Multi-species fishpond and nutrients balance. In Fishponds in Farming Systems, edited by ven der Zijpp, A.J., Verreth, A.J.A., Tri, L.Q., ven Mensvoort, M.E.F., Bosma, R.H. \& Beveridge, M.C.M. Netherlands: Wageningen Academic Publishers.

Rahman, M.M., Kadowaki, S., Linn, S.M. \& Yohei, Y. 2012. Effects of protein skimming on water quality, bacterial abundance and abalone growth in land based recirculating aquaculture systems. Journal of Fisheries and Aquatic Science 7: 150-161.

Rahman, M.M., Kadowaki, S., Balcombe, S.R. \& Wahab, M.A. 2010. Common carp (Cyprinus carpio L.) alter their feeding niche in response to changing food resources: Direct observations in simulated ponds. Ecological Research 25: 303-309.

Rahman, M.M., Jo, Q., Gong, Y.G., Miller, S.A. \& Hossain, M.Y. 2008a. A comparative study of common carp (Cyprinus carpio L.) and calbasu (Labeo calbasu Hamilton) on bottom soil resuspension, water quality, nutrient accumulations, food intake and growth of fish in simulated rohu (Labeo rohita Hamilton) ponds. Aquaculture 285: 78-83.

Rahman, M.M., Verdegem, M., Nagelkerke, L., Wahab, M.A., Milstein, A. \& Verreth, J. 2008b. Effects of common carp Cyprinus carpio (L.) and feed addition in rohu Labeo rohita (Hamilton) ponds on nutrient partitioning among fish, plankton and benthos. Aquaculture Research 39: 85-95.

Rahman, M.M., Verdegem, M.C.J. \& Wahab, M.A. 2008c. Effects of tilapia (Oreochromis nilotica L.) addition and artificial feeding on water quality, and fish growth and production in rohu-common carp bi-culture ponds. Aquaculture Research 39: $1579-1587$.

Rahman, M.M., Verdegem, M.C.J., Nagelkerke, L.A.J., Wahab, M.A. \& Verreth, J.A.J. 2008d. Swimming, grazing and social behaviour of rohu Labeo rohita (Hamilton) and common carp Cyprinus carpio (L.) in tanks under fed and non-fed conditions. Applied Animal Behaviour Science 213: 255-264.

Rajkumar, M., Rahman, M.M., Reni Prabha, A. \& Phukan, B. 2013. Effect of cholymbi on growth, proximate composition, and digestive enzyme activity of fingerlings of long whiskered catfish, Mystus gulio (Actinopterygii: Siluriformes: Bagridae). Acta Ichthyol Piscat 43: 15-20.

Russell, M. 2007. Protecting common coral trout (Plectropomus leopardus) spawning aggregations in the Great Barrier Reef marine park, Australia. Gulf and Caribbean Fisheries Institute 58: 276-280.

Rychly, J. 1980. Nitrogen balance in trout. II. Nitrogen excretion after feeding diets with varying protein and carbohydrate levels. Aquaculture 20: 343-350.

Shiau, S.Y. \& Huang, S.L. 1989. Optimal dietary protein level for hybrid tilapia (Oreochromis niloticus $\times$ O.aureus) reared in seawater. Aquaculture 81: 119-127. 
Solorzano, L. 1969. Determination of ammonia in natural waters by the phenol hypocholorite method.Limnol.Oceanogr. 14: 799-801.

Stone, D.A., Allan, G.L. \& Anderson, A.J. 2003. Carbohydrate utilization by juvenile silver perch, Bidyanus bidyanus (Mitchell). III. The protein-sparing effect of wheat starch based carbohydrates. Aquaculture Research 34: 123 \& 134.

Taguchi, S., Ito-Oka, E., Masuyama, K., Kasahara, I. \& Goto, K. 1985. Application of organic solvent-soluble membrane filters in the preconcentration and determination of trace elements: Spectrophotometric determination of phosphorus as phosphomolybdenum blue. Talanta 32: 391-394.

van Waarde, A. 1983. Aerobic and anaerobic ammonia production by fish. Comparative Biochemistry and Physiology 74: 675-684.

Xia, S., Li, Y., Wang, W., Rajkumar, M., Kumaraguru, vasagam, K.P. \& Wang, H. 2010. Influence of dietary protein levels on growth, digestibility, digestive enzyme activity and stress tolerance in white-leg shrimp, Litopenaeus vannamei (Boone, 1931), reared in high-density tank trials. Aquaculture Research 41: 1845-1854.

Yang, M., Wang, Y., Fu, S., Shen, M., Zheng, F., Wang, G., Yin, S. $\& \mathrm{Li}, \mathrm{X} .2012$. Effects of different temperatures and salinities and $\mathrm{pH}$ values on the early development of Plectropomus leopardus Lacépède. Journal of Tropical Ecology 3: 104-108.

Yang, S., Liou, C. \& Liu, F. 2002. Effects of dietary protein level on growth performance, carcass composition and ammonia excretion in juvenile silver perch (Bidyanus bidyanus). Aquaculture 213: 363-372.

Zhu,Z.Y. \& Yue, G.H. 2008. The complete mitochondrial genome of red grouper Plectropomus leopardus and its applications in identification of grouper species. Aquaculture 276: 44-49.
S. Xia, Z. Sun* \& S. Feng

Tianjin Fisheries Research Institute

Tianjin 300221

P.R. China

\section{Z. Zhang}

Tianjin Fisheries Technology Promotion Station

Tianjin 300221

P.R. China

M.M. Rahman \& M. Rajkumar

Institute of Oceanography and Maritime Studies

International Islamic University Malaysia

Kg. Cherok Paloh

26160 Kuantan, Pahang

Malaysia

M.M. Rahman

Department of Marine Science, Kulliyyah of Science International Islamic University Malaysia

Jalan Istana, Bandar Indera Mahkota

25200 Kuantan, Pahang

Malaysia

*Corresponding author; email: szhj1967@sina.com

Received: 3 July 2014

Accepted: 25 November 2014 